\title{
Interest of pregnant women in the use of SMS (short message service) text messages for the improvement of perinatal and postnatal care
}

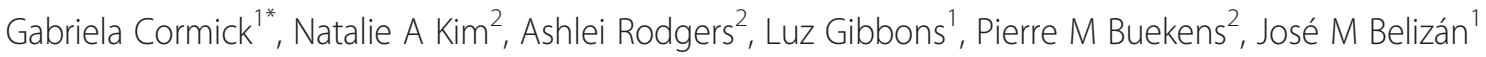
and Fernando Althabe ${ }^{1}$

\begin{abstract}
Background: Mobile health (mHealth) is emerging as a useful tool to improve healthcare access especially in the developing world, where limited access to health services is linked to poor antenatal care, and maternal and perinatal mortality.

The objective of this study is to 1) understand pregnant women's access and usage of cell phones and 2) survey the health information needs and interests in a population attending public hospitals and health centers of two cities in Argentina. This information is not available and it is the basis to develop a strategy for improving maternal care via cell phones.
\end{abstract}

Methods: Questionnaires were verbally administered to pregnant women who were attending an antenatal care visit in community health centers and public hospitals in Rosario, Santa Fe and Mercedes, Corrientes. Participants were 18 years of age or older and had previously given birth. The data obtained was qualitative and analyzed using SPSS version 18.

Results: A total of 147 pregnant women meeting inclusion criteria (Rosario: 63; Mercedes: 84) were approached and verbally consented to participate. The average age was 29.5 years, most lived in urban areas (89\%) with a mean travel time of 43.4 minutes required to get to the health center and 57.3 minutes to get the hospital.

Ninety-six percent of women $(n=140)$ responded that they would like to receive text messages and cell phone calls with information regarding prenatal care, although the topics and period of time to receive information varied greatly.

Conclusions: Considering the vast majority of the interviewed women had access to and were interested in receiving text messages and calls with educational information regarding pregnancy and infant health, pregnant women in Argentina could benefit from such an mHealth program. The low access to Internet suggests it is not an option for this population; however, this cannot be assumed as representative of the country's situation.

To retain active participation, other forms of health communication, such as a 2-way text message systems or toll-free numbers, could be considered in the future. Cost of use and implementing these options should be studied.

Keywords: mHealth, Mobile health, SMS text messages, Perinatal, Prenatal, Healthcare, Argentina

\footnotetext{
* Correspondence: gabmick@yahoo.co.uk

'Department of Mother \& Child Health Research, Institute for Clinical

Effectiveness and Health Policy (IECS), Dr. Emilio Ravignani 2024, Buenos

Aires C1414CPV, Argentina

Full list of author information is available at the end of the article
} 


\section{Background}

Mobile health (mHealth) is emerging as a useful tool to improve access to health especially in areas with a limited health care workforce, limited financial resources, and a high burden of disease such as the developing world [1]. Short message service (SMS) has the potential to affect behavioral change due to its efficiency, low cost, and capability of disseminating health information to hard-to-reach populations [2].

Economically disadvantaged populations commonly use health services less. A review on access to health in low- and middle- income countries shows a lack of proper evidence on ways to reduce limiting barriers; especially those on the demand end related to the lack of education and information, the cost of access, and cultural issues [3].

Limited access to health services is linked to low antenatal care and maternal and perinatal mortality [4]. mHealth could be a very useful strategy for low- and medium- income countries to improve antenatal care. as it is suggested by programs implemented in Zanzibar, Tanzania (Wired Mothers) [5], the United States (Text4Baby) [6], and Serbia (Beba Dolazi) [7] in which gestational period specific text messages are sent to subscribed women to provide educational material, however the impact of this programs is still in evaluation [8-10]. We proposed this study as a crucial initial step to design and test a mHealth strategy to address this problem in Argentina.

The objective of this study was to understand pregnant women's level of access to cell phones, behaviors of cell phone usage, and information needs and interests in a population attending public hospitals and health centers of two cities of Argentina. This information is not available in the literature and is the basis to develop a strategy using cell phones for the improvement of maternal care.

\section{Methods}

Questionnaires were administered to assess knowledge, attitude and behaviors surrounding mobile phone and text message use among pregnant women in community health centers and public hospitals in Rosario, Santa Fe (Maternidad Martin and Roque Saenz Peña Hospital) and Mercedes, Corrientes (Las Mercedes Hospital, Axel Verón Health Center, San Francisco Health Center, and San Martin Health Center). Rosario is a city of around 1.5 million inhabitants while Mercedes is a city of around 40,000 inhabitants surrounded by a wide rural area. The two sites in Rosario were selected based on that they are the biggest hospitals in the city assisting around $60 \%$ of its public deliveries. In Corrientes, the selection was made based on a representation of the various sites providing antenatal care, a unique hospital and 3 peripheral health centres.
The public health sector in Argentina provides free health care to all population; however it is mainly used by the population whose health care is not provided by labor union insurance funds or the private sector [11]. This group represented $38 \%$ of the population during the 2010 census and is identified as the less socioeconomically advantaged. This group represents more than $48 \%$ of the population in province of Corrientes and around $32 \%$ in the province of Santa Fe [12,13]. On average, $14 \%$ of this population live in rural areas, with some northern provinces averaging more than $25 \%$, and presumably face more difficulties in accessing health services [14].

The inclusion criteria of the study required the participants to be pregnant women, at least 18 years, who had previously given birth to a live fetus. We decided to include only women who had previously given birth to a live fetus as some questions relate to late pregnancy or postpartum experiences, which women in their first pregnancy would not have had. Pregnant women included in this study were able to recall their previous experience to answer the questions of this study.

Sampling was performed by convenience. Interviewers recruited all eligible women in each site until completing the sample number. As Mercedes had more centers all women included the last day exceeded the final sample number. All eligible participants were verbally asked for informed consent in Spanish, which was approved by the Institutional Review Board of Tulane University and the Ethics Committee of the Center of Medical Education and Clinical Investigations in Buenos Aires, Argentina.

During prenatal clinic hours, research personnel approached patients in waiting rooms prior to patients' appointments. Subjects were taken to a quiet area in the waiting room and asked to verbally answer the questionnaires, which took an average of 20 minutes total. This interview included demographic characteristics, use of technology and willingness to receive information via mobile phone. We also asked about travel time to the health centre and to the hospital. Interviewers received training on interviewing techniques and information regarding mHealth. The completed questionnaires were stored in binders in the nurse's station until collected by head research staff.

Data was entered into Excel spreadsheets and means and standard deviations were analyzed using SPSS version 18. Sample size of 60 subjects in each location was estimated assuming $80 \%$ of cell phones availability with $\mathrm{a}+/-10 \%$ error in the estimation and a confidence level of $95 \%$.

\section{Results}

A total of 147 pregnant women meeting the inclusion criteria, 63 in Rosario and 84 in Mercedes, were 
approached and verbally consented in hospital and health center waiting rooms. None of the subjects declined to participate, although one subject had to leave before the completion of all three questionnaires.

Table 1 provides the demographic characteristics of women interviewed. The average age was 29.5 years, most lived in urban areas $(89 \%)$ with a mean travel time of 43.4 minutes required to get to the health center and 57.3 minutes to get to the hospital, although this varied greatly among the sites. Twenty-five of them (17.1\%) reported not having completed primary school.

Of 146 subjects, 136 women (93.2\%) were using cell phones at the time of the interview; fifty-six of whom
(38.4\%) have had the same phone number for more than one year (Table 2 ). The majority $(74.7 \%)$ was using a prepaid cell phone method versus a contracted plan. The average age of first cell phone ownership was 22.2 years with a standard deviation of 5.7 years. Very few subjects $(\mathrm{n}=6 ; 4.1 \%)$ had and used the internet on their cell phones while the majority (61\%) did not use internet regularly neither on cell phones or on computers.

One hundred and forty (96\%) responded that they would like to receive text messages with information regarding prenatal care (Table 3 ). While women consistently showed interest in receiving the informational text messages, the time at which they would want to begin

Table 1 Demographic Information

\begin{tabular}{|c|c|c|c|c|}
\hline Characteristics & & \multirow{2}{*}{$\frac{\text { Mercedes }(n=83)}{n(\%)}$} & \multirow{2}{*}{$\frac{\text { Rosario }(n=63)}{n(\%)}$} & \multirow{2}{*}{$\frac{\text { All }(n=146)}{n(\%)}$} \\
\hline & & & & \\
\hline \multirow{3}{*}{$\begin{array}{l}\text { Age (years) (the study included only } \\
\text { women over 18) }\end{array}$} & Less than 20 & $2(2.4)$ & $2(3.2)$ & $4(2.7)$ \\
\hline & 20 to 34 & $55(66.3)$ & $56(88.9)$ & $111(76.0)$ \\
\hline & 35 and more & $26(31.3)$ & $5(7.9)$ & $31(21.2)$ \\
\hline \multirow[t]{2}{*}{ Country of birth } & Argentina & $79.0(95.2)$ & $60.0(95.2)$ & $139.0(95.2)$ \\
\hline & Other & $4.0(4.8)$ & $3.0(4.8)$ & $7.0(3.5)$ \\
\hline \multirow[t]{3}{*}{ Area of residence } & Urban & $71.0(85.5)$ & $59.0(93.7)$ & $130.0(89.0)$ \\
\hline & Rural & $8.0(9.6)$ & $2.0(3.2)$ & $10.0(6.8)$ \\
\hline & No response & $4.0(4.8)$ & $2.0(3.2)$ & $6.0(4.1)$ \\
\hline \multirow{4}{*}{$\begin{array}{l}\text { Travel time required to get to the health } \\
\text { center (in minutes) }\end{array}$} & Less than 30 & $45(54.9)$ & $51(81.0)$ & $96(66.2)$ \\
\hline & 30 to 59 & $15(18.3)$ & $7(11.1)$ & $22(15.2)$ \\
\hline & 60 to 119 & $8(9.8)$ & $4(6.3)$ & $12(8.3)$ \\
\hline & 120 or more & $14(17.1)$ & $1(1.6)$ & $15(10.3)$ \\
\hline \multirow{5}{*}{$\begin{array}{l}\text { Travel time required to get to the } \\
\text { hospital (in minutes) }\end{array}$} & Less than 30 & $14(16.8)$ & $25(39.7)$ & $39(26.7)$ \\
\hline & 30 to 59 & $28(34.1)$ & $33(52.4)$ & $61(41.8)$ \\
\hline & 60 to 119 & $26(31.7)$ & $4(6.3)$ & $30(20.5)$ \\
\hline & 120 or more & $14(17.4)$ & $1(1.6)$ & $15(10.3)$ \\
\hline & Missing & $1(1.2)$ & $0(0.0)$ & $1(0.7)$ \\
\hline \multirow[t]{2}{*}{ Number of people in the household } & Less than5 & $31(37.3)$ & $34(54.0)$ & $65(44.5)$ \\
\hline & 5 or more & $52(62.7)$ & $29(46.0)$ & $81(55.5)$ \\
\hline \multirow[t]{3}{*}{ Number of previous births } & $1-2$ & $43(51.8)$ & $46(73.0)$ & $89(61.0)$ \\
\hline & $3-4$ & $17(20.5)$ & $14(22.2)$ & $31(21.2)$ \\
\hline & 5 or more & $23(27.7)$ & $3(4.8)$ & $26(17.8)$ \\
\hline \multirow[t]{3}{*}{ Number of children } & $1-2$ & $44(53.0)$ & $46(73.0)$ & $90(61.6)$ \\
\hline & 3 to 4 & $16(19.3)$ & $14(22.2)$ & $30(20.5)$ \\
\hline & 5 or more & $23(27.7)$ & $3(4.8)$ & $26(17.8)$ \\
\hline \multirow[t]{7}{*}{ Women education level } & Less than primary school & $5(6.0)$ & $0.0(0.0)$ & $5.0(3.4)$ \\
\hline & Primary education, incomplete & $15(18.1)$ & $5(7.9)$ & $20(13.7)$ \\
\hline & Primary education, complete & $22(26.5)$ & $16(25.4)$ & $38(26.0)$ \\
\hline & Secondary education, incomplete & $25(30.1)$ & $19(30.2)$ & $44(30.1)$ \\
\hline & Secondary education, complete & $13(15.7)$ & $18(28.6)$ & $31(21.2)$ \\
\hline & Higher education, incomplete & $1(1.2)$ & $3(4.8)$ & $4(2.7)$ \\
\hline & Higher education, complete & $2(2.4)$ & $2(3.2)$ & $4(2.7)$ \\
\hline
\end{tabular}


Table 2 Use of mobile phones and internet

\begin{tabular}{|c|c|c|c|c|}
\hline & & Mercedes $(n=83)$ & Rosario $(n=63)$ & All $(n=146)$ \\
\hline & & n (\%) & n (\%) & n (\%) \\
\hline \multirow[t]{2}{*}{ Currently have a cell phone } & Yes & 79 (95.2) & $57(90.5)$ & $136(93.2)$ \\
\hline & No & $4(4.8)$ & $6(9.5)$ & $10(6.8)$ \\
\hline \multirow[t]{5}{*}{ Length of time having cell phone } & $<6$ months & $9(10.8)$ & $16(25.4)$ & $25(17.1)$ \\
\hline & 6 months to less than 1 year & $9(10.8)$ & $4(6.3)$ & $13(8.9)$ \\
\hline & 1 year to less than 2 years & $10(12)$ & $15(23.8)$ & $25(17.1)$ \\
\hline & 2 years or more & $49(59)$ & $26(41.3)$ & $75(51.4)$ \\
\hline & Don't know/No response & $6(7.2)$ & $2(3.2)$ & $8(5.4)$ \\
\hline \multirow[t]{3}{*}{ Cell phone plan } & Contract & $10(12)$ & $23(36.5)$ & $33(22.6)$ \\
\hline & Prepaid & $69(83.1)$ & $40(63.5)$ & $109(74.7)$ \\
\hline & Don't know & $4(4.8)$ & $0(0)$ & $4(2.7)$ \\
\hline \multirow[t]{5}{*}{ Age at first cell phone } & Less than 15 & $0(0.0)$ & $1(1.6)$ & $1(0.7)$ \\
\hline & 15 to 1920 & $23(27.7)$ & $29(46.0)$ & $52(35.6)$ \\
\hline & 20 to $<35$ & $52(62.7)$ & $30(47.6)$ & $82(56.2)$ \\
\hline & 35 or more & $3(3.6)$ & $2(3.2)$ & $5(3.4)$ \\
\hline & Missing & $5(6.0)$ & $1(1.6)$ & $6(4.1)$ \\
\hline \multirow[t]{5}{*}{ Changed cell number in the last 12 months } & Never & $22(26.5)$ & $34(54)$ & $56(38.4)$ \\
\hline & 1 time & $26(31.3)$ & $13(20.6)$ & $39(26.7)$ \\
\hline & 2 times & $22(26.5)$ & $8(12.7)$ & $30(20.5)$ \\
\hline & 3 times & $3(3.6)$ & $4(6.3)$ & $7(4.8)$ \\
\hline & 4 or more times & $5(6)$ & $4(6.3)$ & $9(6.2)$ \\
\hline \multirow[t]{3}{*}{ Use of internet on the cell phone } & Yes & $3(3.6)$ & $3(4.8)$ & $6(4.1)$ \\
\hline & No access & $54(65.1)$ & $31(49.2)$ & $85(58.2)$ \\
\hline & No response & $26(31.3)$ & $29(46.0)$ & $55(37.7)$ \\
\hline \multirow[t]{6}{*}{ Location of the computer for internet use } & Home & $17(20.5)$ & $20(31.7)$ & $37(25.3)$ \\
\hline & Call centre & $5(6.0)$ & $2(3.2)$ & $7(4.8)$ \\
\hline & Work/school & $3(3.6)$ & $3(4.8)$ & $6(4.1)$ \\
\hline & Friend/Family & $1(1.2)$ & $2(3.2)$ & $3(2.1)$ \\
\hline & No regular use of internet & $53(63.9)$ & $36(57.1)$ & $89(61.0)$ \\
\hline & No response & $4(4.8)$ & $0(0)$ & $4(2.7)$ \\
\hline
\end{tabular}

receiving text messages varied greatly (before pregnancy: 11\%; month 1: $33 \%$; month 3: $23 \%$; month 6: $14 \%$; last month of pregnancy: 14\%). One hundred and thirty three women (91\%) responded with interest in receiving informational text messages postpartum; again, for varying amounts of time (up to 3 months: 25\%; up to 6 months 38\%; up to 12 months: $17 \%$; more than 12 months: $7 \%)$. More than half of them preferred to receive text messages with a frequency of once a week. An equally large percentage of women were interested in receiving phone calls with similar prenatal (87\%) and postnatal $(87 \%)$ educational information.

Overall, the women were interested in finding out all information regarding pregnancy and newborn health, especially including prenatal (90\%) and infant (91\%) dietary information, activities/things to avoid during pregnancy (92\%), when to call a doctor during pregnancy (91\%), lactation counseling (91\%), and infant skin care
(95\%). The topics with lowest interest included physical activity during pregnancy (73\%) and pregnancy/delivery course information (64\%).

Even though we cannot statistically compare the results obtained from both cities, the sample from Mercedes included more women who were older than 35 years (31.3\% compared to $7.9 \%$ in Rosario) and that took more than 120 minutes to reach the health centre or the hospital (17\% compared to $1.6 \%$ in Rosario).

A similar number of women from both cities reported having a cell phone, however a larger number of women in Mercedes reported having a cell phone for more than 2 years (59\% compared to 41.3) and fewer reported not having changed the number in the last year $(26.5 \%$ compared to $54 \%$ ).

The preferred information to be received by SMS was similar in both groups, although more women in Mercedes were interested in receiving appointment reminders 
Table 3 Willingness to receive health information via mobile phone or internet

\begin{tabular}{|c|c|c|c|c|}
\hline Text messages & & $\frac{\text { Mercedes }(n=83)}{n(\%)}$ & $\frac{\text { Rosario }(n=63)}{n(\%)}$ & $\frac{\text { All }(n=146}{n(\%)}$ \\
\hline \multirow[t]{3}{*}{ Willingness to receive SMS during pregnancy } & Yes & $78(94.0)$ & $62(98.4)$ & $140(95.9)$ \\
\hline & No & $2(2.4)$ & $1(1.6)$ & $3(2.1)$ \\
\hline & Don't know & $3(3.6)$ & $0(0.0)$ & $3(2.1)$ \\
\hline \multirow[t]{6}{*}{ Time to begin receiving SMS } & Before pregnancy & $9(10.8)$ & $7(11.1)$ & $16(11)$ \\
\hline & From month 1 & $39(47)$ & $9(14.3)$ & $48(32.9)$ \\
\hline & From month 3 & $16(19.3)$ & $17(27)$ & $33(22.6)$ \\
\hline & From month 6 & $6(7.2)$ & $14(22.2)$ & $20(13.7)$ \\
\hline & From month 9 (before birth) & $6(7.2)$ & $15(23.8)$ & $21(14.4)$ \\
\hline & Don't know/No response & $7(8.4)$ & $1(1.6)$ & $8(5.4)$ \\
\hline Willingness to receive SMS, post-partum & Yes & $75(90.4)$ & $58(92.1)$ & $133(91.1)$ \\
\hline \multirow[t]{5}{*}{ Period to receive SMS, post-partum } & 0 to 2 months & $13(15.7)$ & $23(36.5)$ & $36(24.7)$ \\
\hline & 3 to 5 months & $40(48.2)$ & $16(25.4)$ & $56(38.4)$ \\
\hline & 6 to 11 months & $12(14.5)$ & $13(20.6)$ & $25(17.1)$ \\
\hline & 12 months or more & $4(4.8)$ & $6(9.5)$ & $10(6.8)$ \\
\hline & Don't know/No response & $14(16.8)$ & $5(7.9)$ & $19(13)$ \\
\hline \multirow[t]{5}{*}{ Preferred time of the day for receiving SMS } & Morning (8 am - before12pm) & $31(37.3)$ & $21(33.3)$ & $52(35.6)$ \\
\hline & Afternoon (12 pm - before 4 pm) & $11(13.3)$ & $7(11.1)$ & $18(12.3)$ \\
\hline & Evening (4 pm - before 8 pm) & $7(8.4)$ & $10(15.9)$ & $17(11.6)$ \\
\hline & Any time & $30(36.1)$ & $23(36.5)$ & $53(36.3)$ \\
\hline & Don't know/No response & $4(4.8)$ & $2(3.2)$ & $6(4.1)$ \\
\hline \multirow[t]{5}{*}{ Preferred frequency to receive SMS } & 1 per week & $40(48.2)$ & $37(58.7)$ & $77(52.7)$ \\
\hline & 3 per week & $31(37.3)$ & $13(20.6)$ & $44(30.1)$ \\
\hline & 5 per week & $2(2.4)$ & $1(1.6)$ & $3(2.1)$ \\
\hline & 7 per week & $6(7.2)$ & $9(14.3)$ & $15(10.3)$ \\
\hline & Don't know/No response & $4(4.8)$ & $3(4.8)$ & $7(4.8)$ \\
\hline \multirow[t]{9}{*}{ Preferred pregnancy information } & Activities/things to avoid & 76 (91.6) & $59(93.7)$ & $135(92.5)$ \\
\hline & When to call a doctor & $77(92.8)$ & $56(88.9)$ & $133(91.1)$ \\
\hline & Diet & $70(84.3)$ & $62(98.4)$ & $132(90.4)$ \\
\hline & Appointment reminders & $79(95.2)$ & $40(63.5)$ & $119(81.5)$ \\
\hline & Family planning & $73(88)$ & $45(71.4)$ & $118(80.8)$ \\
\hline & What to expect at various stages of pregnancy & $70(84.3)$ & $46(73)$ & $116(79.5)$ \\
\hline & Mental health & $73(88)$ & $41(65.1)$ & $114(78.1)$ \\
\hline & Physical activity & $61(73.5)$ & $45(71.4)$ & $106(72.6)$ \\
\hline & Pregnancy \& delivery courses & $69(83.1)$ & $24(38.1)$ & $93(63.7)$ \\
\hline \multirow[t]{5}{*}{ Preferred infant information } & Baby skin care & $77(92.8)$ & $62(98.4)$ & $139(95.2)$ \\
\hline & Diet & $74(89.2)$ & $59(93.7)$ & $133(91.1)$ \\
\hline & Lactation & 76 (91.6) & $57(90.5)$ & $133(91.1)$ \\
\hline & When to call a doctor & $74(89.2)$ & $56(88.9)$ & $130(89)$ \\
\hline & Appointment reminders & $79(95.2)$ & $42(66.7)$ & $121(82.9)$ \\
\hline \multicolumn{5}{|l|}{ PHONE CALLS } \\
\hline Willingness to receive phone calls & Yes & $78(94.0)$ & $49(77.8)$ & $127(87.0)$ \\
\hline \multirow[t]{2}{*}{ during pregnancy } & No & $4(4.8)$ & $12(19.0)$ & $16(11.0)$ \\
\hline & Don't know & $1(1.2)$ & $2(3.2)$ & $3(2.1)$ \\
\hline
\end{tabular}


Table 3 Willingness to receive health information via mobile phone or internet (Continued)

\begin{tabular}{lllll}
\hline Time to begin receiving calls during pregnancy & Before pregnancy & $7(8.4)$ & $4(6.3)$ & $11(7.5)$ \\
\hline & Month 1 & $41(49.4)$ & $5(7.9)$ & $46(31.5)$ \\
\cline { 2 - 5 } & Month 3 & $15(18.1)$ & $14(22.2)$ & $29(19.9)$ \\
\cline { 2 - 5 } & Month 6 & $6(7.2)$ & $10(15.9)$ & $16(11)$ \\
\cline { 2 - 5 } & Month 9 (before birth) & $5(6)$ & $14(22.2)$ & $19(13)$ \\
\cline { 2 - 5 } & Don't know/No response & $6(7.2)$ & $24(16.4)$ \\
\hline \multirow{2}{*}{ Willingness to receive phone calls post-partum } & Yes & $48(94)$ & $12(77.8)$ & $127(87)$ \\
\cline { 2 - 5 } & No & $1(19)$ & $16(11)$ \\
\cline { 2 - 5 } & Don't know & 2(3.2) & $3(2.1)$ \\
\hline
\end{tabular}

(95.2\% compared to 63.5\%) and mental health advice (88\% compared to $65.1 \%$ ) than in Rosario. More women from Mercedes than in Rosario agreed to receive phone calls during pregnancy and post- partum $(94.0 \%$ compared to $77.8 \%)$.

\section{Discussion}

The vast majority of the interviewed women had access to and was open to receive SMS text messages and cell phone calls with educational information regarding pregnancy and infant health. According to our findings, women would be willing to be enrolled in a mHealth one-way text-messaging program at their antenatal visit and receive information via text message regarding everything from prenatal/infant diet, to lactation information, to infant skin care. The most preferred approach was text messages sent out one or three times a week. Ideally, women should be able to choose when and how frequently they would receive text messages. Since a majority of women own cell phones, and report to be interested in receiving educational information via SMS text message, pregnant women in Argentina could benefit from a mHealth program. Owing to the low access to Internet via cell phone and computer, it did not appear to be a good option for communicating with this population.

The results come from two distinct regions of Argentina: Rosario, one of the largest cities of the country, and Mercedes, a small city located in one of the poorest provinces of Argentina. However, we cannot assume that this sample could be representative of the entire population as it was a convenient sample of women interviewed at the health centre or hospital therefore those attending antenatal care more frequently had a greater chance of being included.

A potential drawback to implementing a text-messaging program is that it requires the recipient to have an adequate level of literacy, marginalizing groups who could potentially benefit from the intervention. In our study population this could affect around $17 \%$ of women having no or incomplete primary schooling.
The limitation of sending only 160 characters in a text message poses a challenge for healthcare providers to send detailed messages regarding the health and care of an individual. [15] User guidelines need to be established for mHealth programs to help manage privacy and security issues especially considering mobile phones are often shared among family and community members [16].

To retain active participation, other forms of health communication could be considered in the future such as a 2-way text message systems or toll-free numbers allowing women to express their questions or concerns. Cost of use and implementation of these options should be studied. The increased use of technology can help reduce health care costs by improving efficiencies in the health care system and promoting prevention through behavior change communication.

Although the use of the Internet might have a similar potential in developed countries, this is still not applicable globally [17]. Information in this study performed in two cities from a middle income country shows that the vast majority of women did not have regular access to the internet.

\section{Conclusion}

This study shows that cell phones would be an acceptable approach to provide pregnancy and postpartum support to women of low socioeconomical level in a middle income country, since the vast majority of women interviewed had access to a cell phone and referred it as a desired and accepted mean of communication.

\section{Abbreviations}

mHealth: Mobile health; SMS: Short message service.

\section{Competing interests}

The authors declare that they have no competing interests.

\section{Authors' contributions}

GC participated in study design, data collection/analysis, and manuscript drafting. NK and AR participated in study design, IRB submission, data collection/analysis, and manuscript drafting. LG participated in statistical analysis. PB participated in study design and manuscript drafting. JB participated in study design, study coordination, data interpretation, and 
manuscript drafting. FA participated in study design, and manuscript drafting. All authors read and approved the final manuscript.

\section{Acknowledgement}

The authors wish to thanks the contribution of Alicia del Pino and Tania Lima Perez for the implementation of the survey in Rosario and in Mercedes, Corrientes. The project described was supported by Grant Number T37MD001424 from the National Center for Minority Health and Health Disparities (NCMHD)

\section{Author details}

'Department of Mother \& Child Health Research, Institute for Clinical Effectiveness and Health Policy (IECS), Dr. Emilio Ravignani 2024, Buenos Aires C1414CPV, Argentina. ${ }^{2}$ School of Public Health and Tropical Medicine, Tulane University, 1440 Canal St., Ste. 2430, New Orleans, LA 70112-2705, USA.

Received: 29 March 2012 Accepted: 26 July 2012

Published: 6 August 2012

\section{References}

1. Mechael P, Batavia H, Kaonga N, Searle S, Kwan A, Goldberger A, Fu L, Ossman J: Barriers and gaps affecting mHealth in low and middle income countries. Columbia University: Policy white paper. Center for Global Health and Economic Development, Earth Institute; 2010.

2. International Telecommunication Union (ITU): The World in 2010, ICT Facts and Figures. http://www.itu.int/TU-D/ict/material/FactsFigures2010.pdf.

3. Ensor T, Cooper S: Overcoming barriers to health service access: influencing the demand side. Health Policy Planning 2004, 19(2):69-79.

4. Temple P, Lutenbacher M, Vitale J: Limited access to care and home healthcare. Clin Obstet Gynecol 2008, 51(2):371-384.

5. Noordam AC, Kuepper BM, Stekelenburg J, Milen A: Improvement of maternal health services through the use of mobile phones. Trop Med Int Health 2011, 16(5):622-626.

6. Lund S: Wired Mothers-Use of mobile phones to improve maternal and neonatal health in Zanzibar. http://www.enrecahealth.dk/archive/ wiredmothers.

7. Text4Baby Home Page: http://www.text4baby.org.

8. Mobmed Home Page: http://www.mobimed.org.rs.

9. Evans WD, Abroms LC, Poropatich R, Nielsen PE, Wallace JL: Mobile health evaluation methods: the Text4baby case study. J Health Commun. 2012, 17(Suppl 1):22-29.

10. Parker RM, Dmitrieva E, Frolov S, Gazmararian JA: Text4baby in the United States and Russia: an opportunity for understanding how mHealth affects maternal and child health. J Health Commun. 2012, 17(Suppl 1):30-36.

11. Maceira D: Inequidad en el acceso a la salud en la Argentina. In Cuadernos del CLAEH 2009, 99(2):7-17.

12. Belló M, Becerril-Montekio VM: The health system of Argentina. Salud Publica Mex 2011, 53(2):s96-s108.

13. Acuña CH, Chudnovsky M: El sistema de salud en la Argentina. Buenos Aires: Ciudad de Buenos Aires: Ministerio de Salud. Direccion de Docencia e Investigacion; 2002. http://estatico.buenosaires.gov.ar/areas/salud/dircap/ mat/matbiblio/salud.pdf. (accesed 08-03-2012).

14. Censo 2010: Instituto Nacional de Estadística y Censo. Argentina. http://www. censo2010.indec.gov.ar/index_cuadros.asp.

15. Person MD, Anna K, Michela LM, Blain, Helen J: Text messaging for enhancement of testing and treatment for Tuberculosis, Human Immunodeficiency Virus, and Syphilis: A survey of attitudes toward cellular phones and healthcare. Telemedicine and E-Health 2011, 17(3):189-195.

16. Cole-Lewis H, Kershaw T: Text messaging as a tool for behavior change in disease prevention and management. Epidemiologic Reviews 2010, 32(1):56-69.

17. Lagan BM, Sinclair M, Kernohan WG: What is the impact of the Internet on decision-making in pregnancy? A global study. Birth 2011, 38:336-345.

doi:10.1186/1742-4755-9-9

Cite this article as: Cormick et al: Interest of pregnant women in the use of SMS (short message service) text messages for the improvement of perinatal and postnatal care. Reproductive Health 2012 9:9.

\section{Submit your next manuscript to BioMed Central and take full advantage of:}

- Convenient online submission

- Thorough peer review

- No space constraints or color figure charges

- Immediate publication on acceptance

- Inclusion in PubMed, CAS, Scopus and Google Scholar

- Research which is freely available for redistribution 